\title{
Sosialisasi Sadar Wisata Sebagai Upaya Pengembangan Desa Wisata Berbasis Masyarakat di Desa Fatukoto
}

Yudha Eka Nugraha

Politeknik Negeri Kupang, Kupang, Indonesia, email: yudhaekanugraha@gmail.com

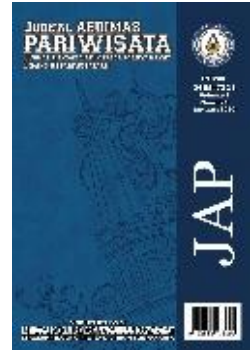

\section{Informasi artikel \\ Sejarah \\ artikel}

Diterima

Revisi

: 1 Desember 2020

Dipublikasikan : 1 Januari 2021

Kata kunci:

Sadar Wisata

Sapta Pesona

Desa Wisata

Pengabdian

Fatukoto
ABSTRAK
Pengembangan Desa Wisata merupakan upaya pemerintah dalam membangun system pariwisata dari desa serta meningkatkan kesejahteraan masyarakat. Pada tahun 2019, Kementerian Pariwisata bekerjasama dengan Perguruan Tinggi untuk membangun desa wisata di Provinsi Nusa Tenggara Timur. Salah satunya di Desa Fatukoto sebagai desa wisata rintisan yang memiliki potensi alam berupa Hutan Pinus, Danau Kaenka, dan Tebing Marmer Fatunausus. Pengabdian masyarakat ini berupaya meningkatkan sadar wisata bagi masyarakat Desa Fatukoto melalui pendekatan SAPTA PESONA. Metode yang dipilih dalam melaksanakan pengabdian masyarakat ini adalah pendidikan masyarakat dimana didalamnya terdapat observasi, wawancara, dokumentasi, focus group discussion, dan sosialisasi. Jumlah peserta yang mengikuti kegiatan pengabdian ini berjumlah 30 orang berusia antara 17-30 tahun. Hasil pengabdian masyarakat ini adalah terbentuknya kelompok sadar wisata Desa Fatukoto dan program kerja pariwisata di Desa Fatukoto seperti rencana kegiatan budaya, regulasi kebersihan daya tarik wisata, dan komitmen untuk membangun desa wisata Fatukoto

ABSTRACT

Keywords:

Tourism Awareness

Sapta Pesona

Rural Tourism

Volunteerism

Fatukoto
Socialization of Tourism Awareness as an Effort to Develop Community-Based Rural Tourism in Fatukoto Village. Rural Tourism Development is a government program to build a village tourism system and improve community welfare. In 2019, the Ministry of Tourism collaborates with universities to build tourist villages in East Nusa Tenggara Province. One of the village is Fatukoto Village as a pilot rural tourism that has natural potential in the form of Pine Forest, Kaenka Lake, and Fatunausus Marble Cliffs. This community service seeks to increase tourism awareness for the people of Fatukoto Village through the SAPTA PESONA approach. The method chosen in implementing this community service is community education in which there are observations, interviews, documentation, focus group discussions, and socialization. The number of participants who took part in this service activity was 30 people aged 17-50 years. The result of this community service is the formation of a tourism awareness group in Fatukoto Village and a tourism work program in Fatukoto Village such as plans for cultural activities, regulations on cleanliness of tourist attractions, and commitment to building Fatukoto tourism villages.

\section{Pendahuluan}

Pengembangan pariwisata di Indonesia telah memasuki babak baru. Selama kurun lima tahun terakhir sejak tahun 2014 sampai 2018, jumlah kunjungan wisatawan menunjukkan kenaikan yang stabil. Rata-rata pertumbuhan kunjungan wisatawan mancanegara (wisman) ke Indonesia dalam lima tahun terakhir (2014-2018) mencapai 14\% per tahun. Angka ini lebih tinggi dibandingkan rata-rata pertumbuhan kunjungan wisman pada periode 2009-2013 yang sebesar 9\% per tahun.Pengembangan yang positif ditangkap oleh pemerintah melalui Kementerian Pariwisata Indonesia untuk 
mempersipakan destinasi wisata yang lebih beragam. Keberagaman potensi wisata Indonesia salah satunya adalah melalui pengelolaan wilayah desa di Indonesia. Pada tahun 2019, Kementerian Pariwisata (Kemenpar) berfokus untuk mengembangkan 2000 desa untuk menjadi desa wisata mandiri.

Pembangunan desa menjadi sebuah desa wisata ini tidak hanya dengan pengembangan destinasi wisatanya saja. Tetapi ada hal lain yang juga tidak kalah penting, yakni pengembangan sumber daya manusia (SDM) sesuai bidangnya masing-masing terutama dalam bidang kepariwisataan.

Pariwisata dikenal sebagai salah satu penggerak kegiatan ekonomi atau prime mover. Hal ini dikarenakan pariwisata menyentuh aspek kehidupan secara menyeluruh, tidak hanya menyentuh kelompok-kelompok tertentu namun juga kalangan bawah. Dalam kegiatan pariwisata, masyarakat lokal dapat terbantu dengan kesempatan kerja di sekitar destinasi wisata atau dapat menjadi tuan rumah dalam bisnis pariwisata. Misalnya kegiatan pariwisata pada desa wisata yang berkembang, terdapat usaha jasa penginapan, transportasi, informasi, penyedia makanan dan minuman, serta penyedia jasa lainnya. Kegiatan pariwisata memberikan dampak ekonomi pada pendapatan masyarakat. Meningkatkan kesejahteraan dan menekan tingkat pengangguran terutama di desa. Dampak positif ini membuat pembangunan pariwisata menjadi salah satu sektor yang diandalkan yang diharapkan mampu untuk setara dengan bidang ekonomi lainnya yang kurang memperhatikan aspek keberlanjutan. Secara jangka Panjang, upaya pengembangan potensi kepariwisataan seperti desa wisata akan membuka berbagai kesempatan bekerja, peningkatan pendapatan masyarakat, serta peningkatan pendapatan daerah dan pendapatan negara. Hal-hal ini menjadikan pengembangan pariwisata terutama desa wisata sangat penting untuk didorong agar maju di Negara Indonesia.

Dalam mendorong terwujudnya kondisi pariwisata berkelanjutan di desa, dengan memperhatikan potensi yang dimiliki desa. Maka diperlukan sebuah pendekatan yang digunakan sebagai kerangka pembangunan desa wisata di Indonesia, salah satu pendekatan yang sering digunakan adalah pariwisata berbasis masyarakat. Pengabdian masyarakat ini fokus pada pengembangan desa wisata dengan pendekatan pariwisata berbasis masyarakat dengan memperhatikan prinsip keselarasan dan keseimbangan antara pelaku pariwisata seperti pemerintah, pihak industri, dan masyarakat. Selain itu, dalam kegiatan pengabdian masyarakat, berbagai pelatihan telah dirancang untuk meningkatkan kreatifitas masyarakat dalam membangun desa wisata serta kondisi masyarakat yang sadar wisata dan sapta pesona. Inti dari kegiatan ini adalah untuk meningkatkan partisipasi masyarakat dalam proses perencanaan, pelaksanaan, pengembangan, sampai dengan pengawasan dan evaluasi.Masyarakat setempat harus dilibat secara aktif dan diberikesempatan untuk berpartisipasi karena tujuan akhir adalah untuk meningkatkan kesejateraan dan kualitas hidup masyarakat.

Sebagai komponen utama dalam pengembangan pariwisata berbasis masyarakat, masyarakat berperan dalam semua bidang pembangunan, termasuk perencana, pengelola, pelaksana, pemantau dan evaluator. Namun, meskipun pembangunan pariwisata berbasis masyarakat mengedepankan faktor masyarakat sebagai komponen utamanya, hal ini tetap membutuhkan partisipasi sektor lain seperti pemerintah dan swasta. Penduduk setempat atau masyarakat yang tinggal di tempat wisata memegang peranan yang sangat penting dalam menjaga keberhasilan pembangunan pariwisata di wilayah tersebut.

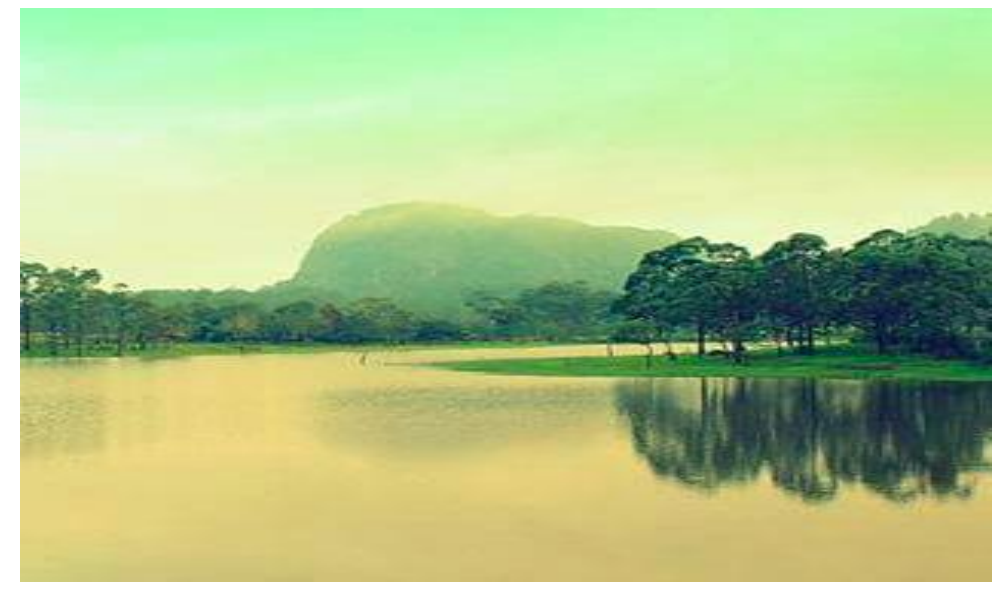

Gambar 1. Potensi Desa Fatukoto 


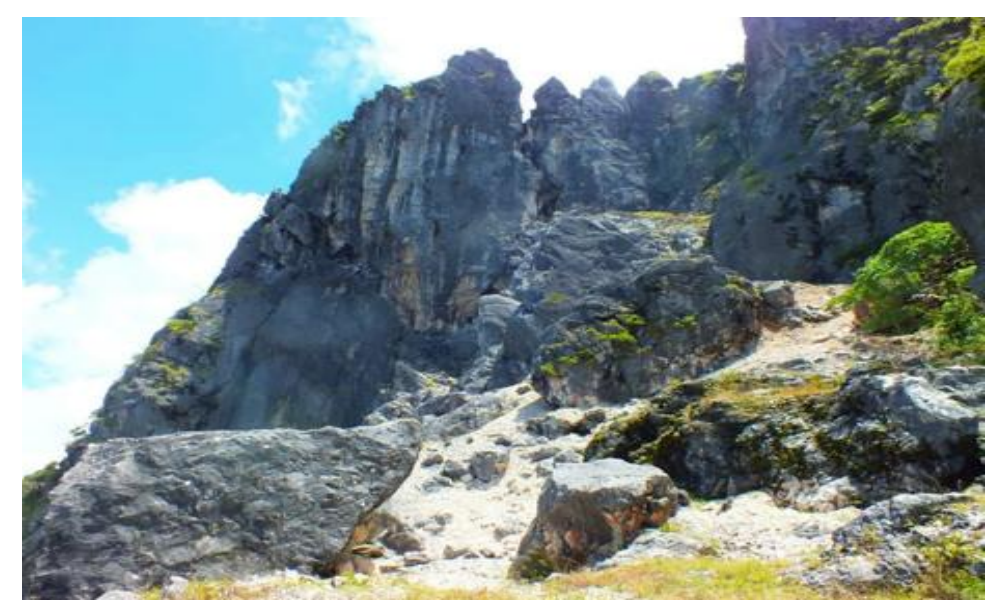

Gambar 2. Potensi Desa Fatukoto

Berkembangnya desa wisata juga mempengaruhi kehidupan sosial dan budaya penduduk sekitarnya. Masuknya wisatawan dengan berbagai macam kebiasaan, lingkungan, tingkat pendidikan, serta latar belakang kehidupan yang berbeda, maka dapat mempengaruhi penduduk yang didatangi baik yang memberi pelayanan langsung maupun tidak langsung (Oka A. Yoeti, 2013).Pariwisata bisa menjadi sarana untuk menambah ilmu, silaturahmi atau gotong royong, namun tidak semua orang bisa melakukan hal tersebut, karena setiap orang memiliki sikap yang berbeda-beda, seperti individualisme akibat kesibukan masing-masing warga. Interaksi antara wisatawan dan penduduk lokal dapat memberikan berbagai wawasan kepada penduduk, seperti pariwisata, budaya, pendidikan, atau aspek lain dari kawasan sumber wisata. Kunjungan singkat oleh wisatawan dapat menjalin kontak dengan penduduk setempat. Pengetahuantentang industri pariwisata masih kurang untuk mengembangkan desa wisata ini. Kedatangan wisatawan sangat membantu untuk pekerjaan pembangunan, karena wisatawan dapat memberikan masukan bagi aparatur pengelola, yang dapat menambah fasilitas dan pelayanan yang lebih baik dimasa yang akan datang.

Salah satu desa yang berpotensi untuk dikembangkan sebagai desa wisata di Pulau Timor adalah Desa Fatukoto. Desa ini memiliki iklim yang sejuk dan ditumbuhi dengan hutan cemara yang menjadi atraksi berbasis alam. Selain itu, terdapat pula danau kaenka, dan tebing marmer yang menjadi atraksi berbasis alam lainnya. Pekerjaan utama masyarakat adalah berkebun, sehingga desa Fatukoto juga memiliki potensi agrowisata yang dapat dikembangkan sebagai atraksi bagi wisatawan. Terdapat perkebunan wortel, jeruk, ubi ungu, jagung, dan berbagai komoditas yang tidak bisa ditemui di dataran lain di Pulau Timor. Keunikan ini dapat dikemas menjadi sebuah produk wisata yang dijual kepada calon wisatawan. Beberapa wisatawan kerap datang melakukan kegiatan seperti camping, melakukan pengamatan alam, dan mendaki ke gunung marmer. Beberapa pengunjung juga membeli hasil kebun warga yang melimpah terutama pada bulan November sampai Mei, waktu hasil perkebunan sedang panen. Namun, Desa Fatukoto belum memiliki pengetahuan mengenai pariwisata. Berdasarkan observasi, pelaku pariwisata di Desa Fatukoto hanya berada pada tataran pemegang kebijakan di desa. Masyarakat umum desa hanya menjadi penonton dan pengelolaannya belum merata. Hal inilah yang menjadi urgensi dalam kegiatan pengabdian masyarakat dengan tema pelatihan dan sosialisasi sadar wisata.

Dengan ditetapkannya pariwissata sebagai prime mover kegiatan ekonomi di Provinsi Nusa Tenggara Timur, maka kegiatan pemerintah untuk mendorong pembangunan desa wisata merupakan upaya untuk dapat mengelola kepariwisataan desa. Pelaku pariwisata dalam hal ini perguruan tinggi wajib melaksanakan pengabdian dalam mendukung program tersebut. Dukungan terhadap program desa wisata dilakukan untuk mempercepat terbentuknya desa wisata, sehingga masyarakat dapat memperoleh manfaat langsung maupun tidak langsung dari pengembangannya. Adapun bentuk pengabdian yang dilakukan oleh instansi pendidikan Jurusan Pariwisata Politeknik Negeri Kupang yakni dengan pendekatan pelatihan dan sosialisasi. Pelatihan ini mengambil tema besar Pelatihan Sadar Wisata bagi masyarakat Desa Fatukoto, di Kabupaten Timor Tengah Selatan.Sadar Wisata istilah yang sering kita dengar dimaksud sebagai partisipasi dan dukungan segenap komponen masyarakat dalam mendorong terwujudnya iklim yang kondusif bagi tumbuh dan berkembangnya 
kepariwisataan di suatu wilayah dan bertujuan untuk meningkatkan kesejahteraan rakyat. Sapta pesona Hamzah \& Utomo (2016)merupakan jabaran konsep sadar wisata yang terkait dengan dukungan dan peran masyarakat sebagai tuan rumah dalam upaya untuk menciptakan lingkungan dan suasana kondusif yang mampu mendorong tumbuh dan berkembnagnya industri pariwisata melalui perwujudan tujuh unsur dalam sapta pesona tersebut. Sapta pesona ada tujuh unsur, yakni aman, tertib, bersih, sejuk, indah, ramah, dan kenangan. Sapta pesona merupakan kondisi yang harus diwujudkan dalam rangka menarik minat wisatawan berkunjung ke suatu daerah atau wilayah tempat wisata.

\section{Metode}

Sebelum kegiatan pengabdian masyarakat dilaksanakan, pendekatan dengan pihak Desa Fatukoto dilakukan terlebih dahulu. Penggalian masalah dilakukan dengan pendekatan kualitatif, dengan Teknik pengumpulan data melalui observasi, wawancara, participatory rural appraisal (PRA) Hudayana, B. et al. (2019), dokumentasi Sugiyono (2016:329) dan penarikan kesimpulan. Setelah mendapatkan permasalahan mengenai adanya gap antara potensi pariwisata Desa Fatukoto yang kaya, namun pengelolaannya masih minim, maka sosialisasi sadar wisata menjadi program untuk mengedukasi masyarakat mengenai pengelolaan desa wisata dalam penerapan 7 unsur sapta pesona. Metode yang digunakan dalam kegiatan pengabdian masyarakat ini adalah pendidikan masyarakat. Peserta yang merupakan penduduk desa Fatukoto berusia 17-50 tahun berjumlah 30 orang akan mendapatkan pelatihan in-house trainingPurwanto (2012: 96)selama 4 hari mengenai sosialisasi sapta pesona. Kemudian peserta akan mendapatkan penyuluhan terkait dengan penerapan praktik sapta pesona di lingkungan desa wisata untuk mendukung pariwisata. Teknik konsultasi juga dilakukan untuk meningkatkan pemahaman masyarakat terkait dengan pengembangan desa wisata. Selain itu, metode selanjutnya dalam kegiatan sosialisasi sadar wisata adalah melalui pembentukan kelompok sadar wisata.

\section{Hasil dan Pembahasan}

\section{Pelaksanaan Sosialisasi Sadar Wisata bagi Masyarakat Desa Fatukoto}

Sosialisasi sadar wisata bertujuan untuk mempromosikan penerapan sapta pesona di destinasi wisata seperti pada desa wisata rintisan di Desa Fatukoto. Komponen dalam sosialisasi sadar wisata mengacu pada 7 unsur sapta pesona yakni: Aman, Tertib,Bersih,Sejuk,Indah, Ramah,dan Kenangan. Sosialisasi dilaksanakan dengan metode in house training di kantor desa Fatukoto diikuti oleh 30 peserta dari berbagai usia. Masyarakat yang dikirim untuk mengikuti pelatihan ini adalah pemuda dan kepala setiap dusun yang berada pada rentang usia 17-50 tahun. Dalam sosialisasi ini, masyarakat didorong untuk melakukan 7 unsur sapta pesona dalam meningkatkan terwujudnya desa Fatukoto sebagai sebuah desa wisata. Berikut adalah hasil diskusi antara fasilitator dan masyarakat yang hadir dalam kegiatan sosialisasi sadar wisata:

Tabel 1. Elaborasi Permasalahan Lapangan Berdasarkan Pendekatan Sapta Pesona

\begin{tabular}{|c|c|c|}
\hline Elemen Sapta Pesona & Pengertian & Hasil FGD Desa Fatukoto \\
\hline Aman & $\begin{array}{l}\text { Suasana yang membuat wisatawan } \\
\text { merasa terlindungi dari tindak } \\
\text { kejahatan }\end{array}$ & $\begin{array}{l}\text { Penerapan keamanan sudah dilaksanakan dan } \\
\text { selalu ditingkatkan. Kendala dalam menerapkan } \\
\text { keamanan di Desa Fatukoto adalah akses yang } \\
\text { jauh dari pusat kota sehingga jalanan masih } \\
\text { rusak, listrik saat malam masih terbatas sehinga } \\
\text { kegiatan wisata tidak bisa dilakukan pada malam } \\
\text { hari. }\end{array}$ \\
\hline Tertib & $\begin{array}{l}\text { Kondisi yang mencerminkan sikap } \\
\text { disiplin yang tinggi serta kualitas } \\
\text { fisik dan layanan yang konsisten } \\
\text { dan teratur serta efisien dalam } \\
\text { memberikan rasa nyaman kepada } \\
\text { wisatawan }\end{array}$ & $\begin{array}{l}\text { Kondisi tertib di Desa Fatukoto dapat ditemukan } \\
\text { pada suasana keteraturan hidup di destinasi } \\
\text { wisata, wisatawan yang datang berkunjung } \\
\text { mayoritas merupakan wisatawan nusantara, tidak } \\
\text { ditemukan antrian, kegiatan wisata dilakukan } \\
\text { sebatas berfoto atau berkemah, lingkungan ditata } \\
\text { secara rapi dan teratur, lingkungan terjaga dengan } \\
\text { asri. }\end{array}$ \\
\hline
\end{tabular}




\begin{tabular}{|c|c|c|}
\hline Bersih & $\begin{array}{l}\text { Kondisi lingkungan destinasi yang } \\
\text { menunjukkan keadaan tempat yang } \\
\text { terpelihara kebersihannya dan bebas } \\
\text { dari segala sampah, limbah, } \\
\text { penyakit, dan pencemaran }\end{array}$ & $\begin{array}{l}\text { Sampah bekas kegiatan wisata ditemukan di } \\
\text { beberapa lokasi, belum ada system pembersihan } \\
\text { lingkungan karena sampah pariwisata. Belum ada } \\
\text { himbauan kebersihan karena kegiatan pariwisata } \\
\text { baru masuk ke Desa Fatukoto }\end{array}$ \\
\hline Sejuk & $\begin{array}{ll}\text { Kondisi lingkungan } & \text { yang } \\
\text { memberikan suasana segar, sehat, } \\
\text { dan nyaman }\end{array}$ & $\begin{array}{l}\text { Masyarakat Desa Fatukoto selalu menjaga } \\
\text { kebersihan dan pelestarian lingkungan. Hal ini } \\
\text { terkait dengan profesi sebagai petani yang } \\
\text { mengharuskan menjaga kebersihan area } \\
\text { pertanian. Selain itu, suhu di desa Fatukoto lebih } \\
\text { dingin sehingga menimbulkan kesan sejuk } \\
\text { dibandingkan dengan destinasi lain yang ada di } \\
\text { Pulau Timor }\end{array}$ \\
\hline Indah & $\begin{array}{l}\text { Kondisi yang mencerminkan } \\
\text { penataan yang teratur, rapi, } \\
\text { menarik, dan serasi hingga } \\
\text { memancarkan keindahan. }\end{array}$ & $\begin{array}{l}\text { Keindahan Desa Fatukoto terkait dengan daya } \\
\text { tarik wisata. Daya tarik wisata di Desa Fatukoto } \\
\text { diantaranya adalah Danau Kaenka, Hutan Pinus, } \\
\text { dan Tebing Marmer. Beberapa daya tarik wisata } \\
\text { buatan juga tersedia seperti bukit dimana tempat } \\
\text { dapat menikmati pemandangan danau dari } \\
\text { ketinggian. }\end{array}$ \\
\hline Ramah & $\begin{array}{l}\text { Sikap dan perilaku yang peduli, } \\
\text { akrab dalam pergaulan, hormat, dan } \\
\text { sopan dalam berkomunikasi, murah } \\
\text { senyum, menyapa, dan memberikan } \\
\text { pelayanan serta kesediaan } \\
\text { membantu tanpa pamrih }\end{array}$ & $\begin{array}{l}\text { Dalam melayani wisatawan, masyarakat desa } \\
\text { belum banyak berpartisipasi, masyarakat masih } \\
\text { sebagai penonton dalam kegiatan pariwisata. } \\
\text { Dikaitkan dengan keramahan, nilai-nilai yang } \\
\text { dianut oleh masyarakat adalah jiwa melayani } \\
\text { sesama sehingga modal hospitality sudah ada } \\
\text { pada masyarakat Desa Fatukoto. }\end{array}$ \\
\hline
\end{tabular}

Sumber: hasil diskusi interaksi bersama peserta sosialisasi sadar wisata, 2019

Sosialisasi sapta pesona dibawakan dengan memancing diskusi antara fasilitator dan masyarakat setempat. Sebagai destinasi yang baru akan dikembangkan, Desa Fatukoto perlu melakukan pemetaan destinasi pariwisata dan menjadikan potensi tersebut sebagai sumber daya yang dikelola dengan baik. Sejauh ini, berdasarkan respon masyarakat, daya tarik utama Desa Fatukoto merupakan destinasi berbasis alam seperti Danau Kaenka tempat dimana wisatawan biasa melakukan perkemahan dan pengamatan bintang, Tebing Marmer, dan Hutan Pinus yang biasa menjadi tempat berfoto wisatawan nusantara.

Sepanjang pelaksanaan sosialisasi, peserta pelatihan antusias untuk mengikuti materi dengan berbagai pertanyaan yang diajukan pada fasilitator. Adapun yang terangkum terkait dengan sapta pesona dijelaskan dalam tabel 1. Dalam tabel tersebut ketujuh elemen unsur sapta pesona diterapkan dalam mengelola Ddaya tarik wisata di Desa Fatukoto. Berdasarkan hasil forum diskusi dalam sosialisasi ini, ditemukan juga tujuh kondisi Desa Fatukoto berdasarkan unsur sapta pesona. Keunggulan Desa Fatukoto terkait ketertiban, keramahan, keindahan, kesejukan, dan kenangan sejauh ini adalah kondisi yang paling baik dibandingkan dengan elemen lainnya. Elemen yang perlu ditingkatkan adalah keamanan dan kebersihan. Elemen keamanan terkait dengan ketersediaan akses jalan yang baik dan nyaman untuk dikunjungi. Kondisi akses jalan ke destinasi wisata di Desa Fatukoto perlu ditingkatkan, kondisi saat ini masih berlumpur (terutama saat hujan) dan berbatu. Sehingga wisatawan tidak dapat melakukan perjalanan dengan kendaraan umum. Terutama saat wisatawan berkunjung ke tebing marmer dan hutan pinus, membutuhkan kendaraan pick up, untuk menuju tebing dan melakukan trekking. Adapun daya tarik wisata yang paling mudah untuk dijangkau adalah Danau Kaenka tempat wisatawan melakukan camping karena berada di jalan yang sudah diaspal. Permasalahan selanjutnya adalah terkait dengan kebersihan, beberapa wisatawan terkadang meninggalkan sampah, walaupun volumenya belum signifikan, namun tidak ada masyarakat yang membersihkan karena belum menyadari pentingnya kebersihan dalam menunjang citra destinasi 
wisata. Oleh karena itu, sosialisasi ini berupaya meningkatkan kesadaran masyarakat untuk melakukan penataan kembali dalam tataran pemerintahan desa mengenai kegiatan pariwisata di Desa Wisata Fatukoto yang mulai bergeliat.

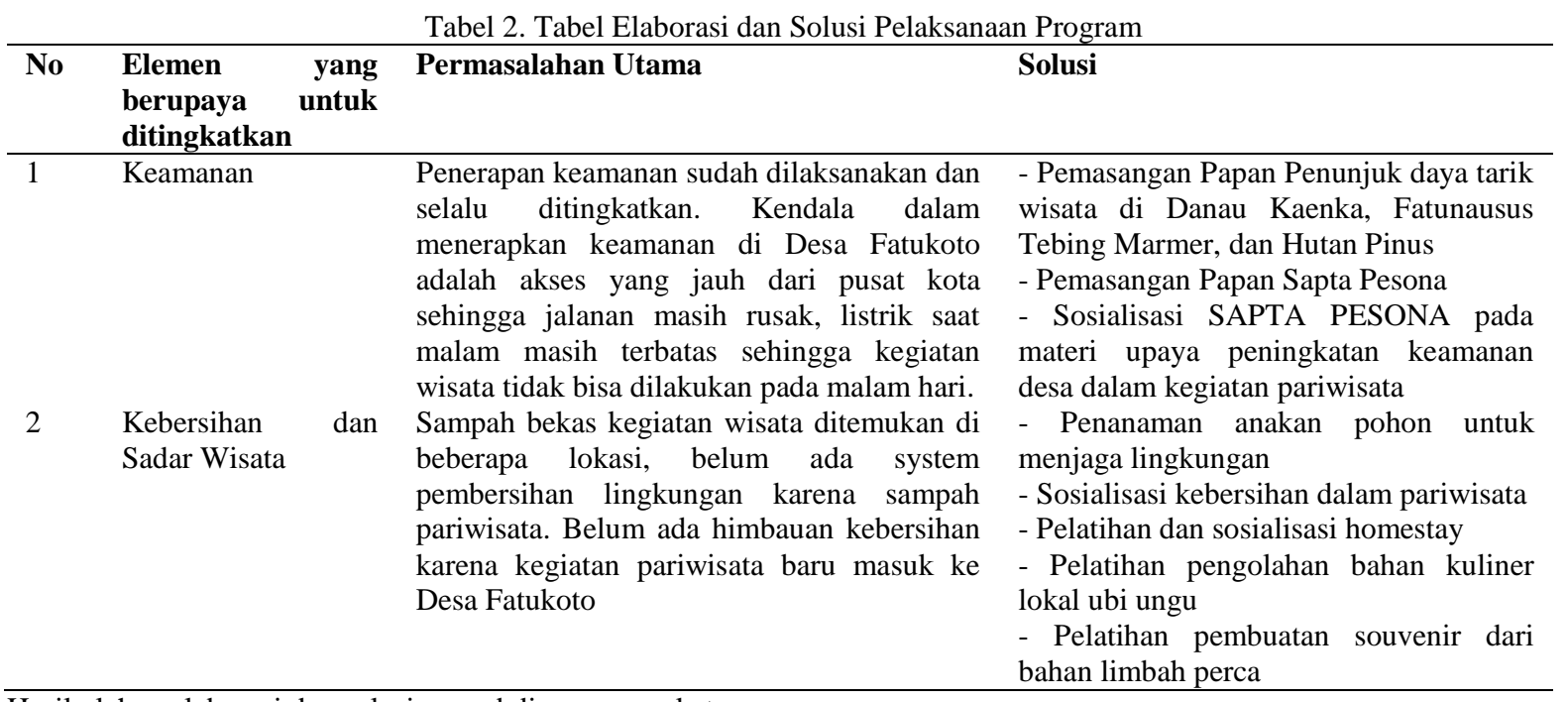

Hasil olahan elaborasi dan solusi pengabdian masyarakat

Berdasarkan hasil elaborasi bersama masyarakat Desa Fatukoto, maka pengabdian yang dilakukan adalah terkait penyelesaian masalah utama dalam hal keamanan, kebersihan, dan peningkatan keterampilan masyarakat setempat sebagai penunjuang kegiatan wisata di Desa Wisata Fatukoto.

\section{Pembuatan Papan Sapta Pesona dan Penunjuk Arah Daya Tarik Wisata}

Kegiatan ini merupakan bentuk pengabdian masyarakat untuk meningkatkan keamanan Desa Fatukoto sebagai desa wisata. Sebagai desa wisata rintisan, Desa Fatukoto membutuhkan berbagai dukungan perlengkapan sebagai papan penunjuk daya tarik wisata. Beberapa wisatawan nusantara sempat kebingungan dan masuk ke desa karena ketiadaan papan penunjuk daya tarik wisata. Papan daya tarik wisata ini terbuat dari kay 1 x 2 meter dan ditonggak dengan kau sepanjang 3 meter. Tujuannya adalah untuk meningkatkan kesadaran mengenai daya tarik wisata di Desa Fatukoto. Papan penunjuk ini juga menjadi sebuah penanda bagi masyarakat setempat untuk menjaga kebersihan di lokasi daya tarik wisata.

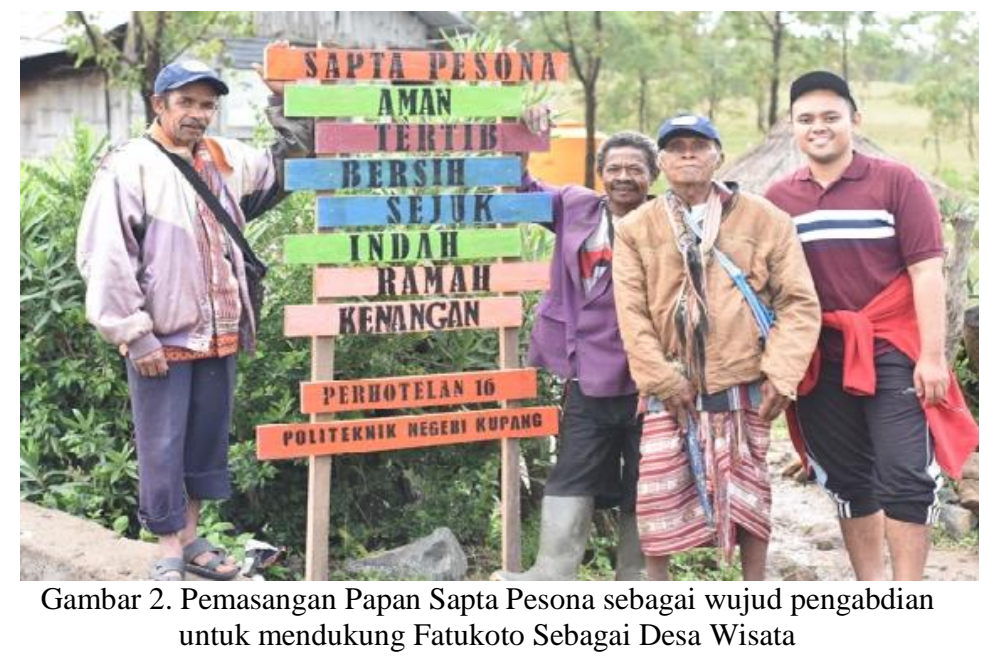

Dalam proses pembuatan papan penunjuk daya tarik wisata dan pemasangannya, tim pengabdian dibantu oleh pemuda dan pemimpin pemerintah Desa di Desa Fatukoto. Hal ini menunjukkan bahwa antusiasme masyarakat dalam pembangunan desa wisata cukup tinggi. Dimulai dari proses sosialisasi sampai dengan pemasangan papan penunjuk. 
Setelah papan penunjuk daya tarik wisata terpasang, kegiatan pengabdian dilanjutkan dengan beberapa pelatihan untuk meningkatkan wawasan masyarakat lokal untuk mempersiapkan Desa Fatukoto sebagai desa wisata rintisan yang memiliki olahan makanan lokal dan souvenir untuk dipromosikan bagi wisatawan yang datang. Sejauh ini, belum ada penyediaan makanan lokal dan souvenir sehingga interaksi antara masyarakat lokal dan wisatawan belum banyak ditemukan. Padahal, jumlah kunjungan wisatawan ke Desa Fatukoto selalu naik dari tahun ke tahun berdasarkan informasi dari pemerintah desa. Selain itu, kegiatan lain yang dilakukan yakni penanaman anakan pohon untuk menambah keasrian lingkungan di Desa Fatukoto dan pelatihan pengelolaan homestay di Desa Fatukoto

\section{Penanaman Pohon dan Pelatihan Desa Wisata}

Penanaman pohon dilakukan di sekitar kantor desa, karena tempat ini cukup lapang sehingga memiliki banyak tempat untuk penanaman pohon. Pohon yang ditanam diantaranya adalah pohon pinus dan pohon peneduh lainnya. Setelah penanaman pohon, kegiatan selanjutnya adalah melakukan pelatihan pengolahan makanan berbahan dasar ubi ungu sebagai olahan kuliner yang disuguhkan kepada wisatawan. Ubi ungu merupakan komoditas lokal yang dihasilkan oleh petani desa Fatukoto. Ubi ini biasa dikonsumsi warga desa sebagai makanan pokok atau pendamping dalam kehidupan sehari-hari. Tim pengabdian melakukan pelatihan olahan ubi ungu dan mengubahnya menjadi klepon ubi ungu. Bahan-bahan yang dibutuhkan adalah tepung beras, gula merah, parutan kelapa, dan ubi ungu. Proses pembuatannya yakni: (1) ubi ungu yang telah dibersihkan dihancurkan sampai lembut, (2) adonan ubi ungu lembut ditambahkan dengan tepung beras, (3) kemudian adonan tersebut dicampur dan diuleni sampai merata dan bisa dibentuk menjadi bola-bola kecil, (4) masukkan gula merah ketengah adonan yang sudah dibentuk menjadi bola, (5) rebus adonan dalam air mendidih selama 10 menit.

Warga desa terutama ibu-ibu sangat antusias dalam mengikuti demo memasak yang dilakukan oleh tim pengabdian. Tercatat perserta pelatihan kuliner lokal ubi ungu ini berjumlah 50 orang. Selain dipertunjukkan oleh fasilitator, peserta pelatihan juga diberi kesempatan untuk membuat sendiri olahan ubi ungu menjadi klepon. Selain itu, masyarakat juga dipandu untuk menyajikannya dengan menerapkan kebersihan alat makan seperti piring dan sendok yang digunakan dan penggunaan tudung saji untuk menghindari lalat yang hinggap di makanan.

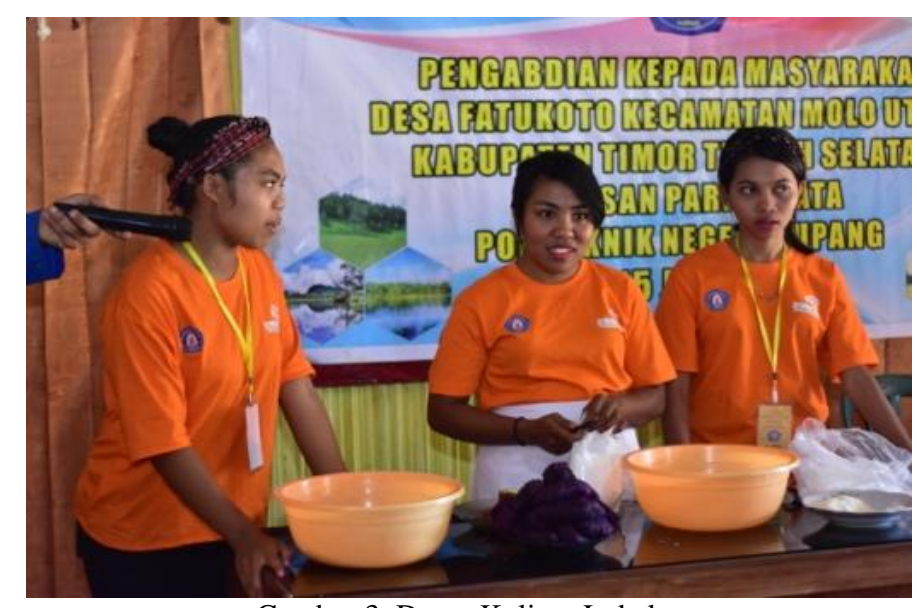

Gambar 3. Demo Kuliner Lokal

\section{Pembentukan Kelompok Sadar Wisata}

Upaya selanjutnya dalam kegiatan pengabdian masyarakat untuk meningkatkan kondisi masyarakat yang sadar wisata adalah pembentukan kelompok sadar wisata. Pembentukan kelompok sadar wisata di DesaFatukoto bertujuan untuk menjadi rekan kerjapemerintah desa untuk menjalankan tugas pengembangan pariwisata di desa. Keberadaan kelompok sadar wisata merupakan salah satu program yang sudah menjadi rencana pihak pemerintah desa, namun berdasarkan hasil penggalian informasi belum dapat dibentuk karena kesibukan aparatur pemerintah desa dan keterbatasan pengetahuan mengenai tugas dan fungsi pokok kelompok sadar wisata dalam suatu desa. 
Pembentukan kelompok sadar wisata dipandu sendiri oleh Kepala Desa Fatukoto yang beranggotakan peserta pelatihan sosialisasi sadar wisata yang sedang dilaksanakan. Proses pembentukan dibantu oleh tim pengabdian untuk menentukan secara sukarela dari inisatif warga yang hadir dalam kegiatan pelatihan. Pada saat penjaringan anggota kelompok sadar wisata, hampir setengah dari jumlah peserta (15 orang) mengajukan diri untuk dapat membangun kepariwisataan melalui kelompok sadar wisata. Secara umur, masyarakat yang mengajukan diri berada dalam rentang umur beragam dari 17 sampai 45 tahun. Seluruh kepala dusun mengajukan diri sebagai anggota kelompok sadar wisata Desa Fatukoto dan sisanya adalah mama-mama penenun dan pemuda desa. Kelompok sadar wisata yang dibentuk bersama-sama dengan tim pengabdian membuat sebuah rancangan program pariwisata untuk meningkatkan geliat pariwisata Desa Fatukoto. Salah satu program yang sedang dirancang untuk mendukung pariwisata lokal adalah penyelenggaraan festival tenun dan kuliner lokal. Festival ini akan dilaksanakan minimal pada tataran pemerintah desa untuk meningkatkan kesadaran masyarakat luas di wilayah Fatukoto tentang pelestarian budaya sebagai bentuk dukungan pada kegiatan pariwisata. Pembentukan kelompok sadar wisata berjalan dengan baik dengan terciptanya program kerja selama satu tahun kedepan untuk pelaksanaan festival tenun dan kuliner lokal.

\section{Simpulan}

Desa Fatukoto Kecamatan Molo Kabupaten Timur Tengah Selatan memiliki potensi pariwisata yang dapat dikembangkan menjadi sebuah Desa Wisata. Potensi tersebut berupa wisata alam yaitu Hutan Pinus, Tebing marmer "Fatunausus", dan Danau "Kaenka". Oleh karena itu, tim pengabdian berupaya melakukan pengembangan Desa Wisata di Desa Fatukoto yang dilaksanakan selama 4 hari untuk menggali informasi sekaligus melakukan berbagai kegiatan sosialisasi dan pelatihan sadar wisata bagi masyarakat Desa Fatukoto.

Kegiatan pengabdian berhasil dilaksanakan dengan mendapat respon baik dari masyarakat Desa Fatukoto dibuktikan dengan jumlah peserta yang mengikuti kegiatan sebanyak 30 orang dengan jabatan sebagai aparatur desa dan pengrajin tenun setempat. Selama proses pengabdian, masyarakat yang hadir secara aktif berpartisipasi memberikan tanggapan sesuai dengan materi sosialisasi sadar wisata yang telah disampaikan. Adapun permasalahan yang masih dihadapi adalah minimnya fasilitas dan perhatian dari pemerintah. Namun, hal ini dapat diatasi secara bertahap dengan mempertahankan sikap masyarakat yang selalu semangat membangun kepariwisataan. Semangat ini dituangkan dengan partisipasi masyarakat dalam kegiatan pelatihan dan niat masyarakat untuk membentuk kelompok sadar wisata Desa Fatukoto.

Kegiatan lain yang dilakukan untuk mendukung pembangunan desa wisata di Fatukoto diantaraya adalah pemasangan papan penunjuk arah destinasi wisata dan papan SAPTA PESONA. Hal ini diupayakan untuk meningkatkan kesadaran warga akan pentingnya informasi dalam kegiatan pariwisata. Selain itu papan SAPTA PESONA merupakan sebuah symbol semangat masyarakat desa untuk selalu menjaga destinasi wisata agar selalu aman dan nyaman didatangi wisatawan. Selesai melakukan pemasangan papan penunjuk arah destinasi, kegiatan dilanjutkan dengan demo kuliner ubi ungu sebagai olahan kreatif klepon ubi ungu yang dapat menjadi daya tarik bagi wisatawan. Antusiasme masyarakat tinggi sehingga jumlah peserta kegiatan meningkat. Hal ini kemudian menjadikan kegiatan pengabdian berjalan ramai dan dilanjutkan dengan kegiatan pelatihan pengelolaan homestay serta penanaman anakan pohon. Pelatihan pengelolaan homestay diakhiri dengan demo pemasangan tempat tidur agar sesuai dengan standar usaha pariwisata dalam bidang jasa akomodasi.

Kegiatan pengabdian yang terakhir adalah pembentukan kelompok sadar wisata Desa Wisata Fatukoto. Pembentukan kelompok sadar wisata diminati oleh sekitar 15 orang masyarakat setempat dan ditetapkan untuk menjadi pelaksana pengembangan desa wisata bersama dengan pemerintah desa. Adapun kegiatan yang akan dilaksanakan oleh kelompok sadar wisata desa Fatukoto untuk mempromosikan pariwisata setempat adalah festival tenun dan kuliner lokal. Kedepannya, kegiatan pengabdian masyarakat ini akan selalu dipantau oleh tim perguruan tinggi untuk tetap menjaga keberlanjutan program dan menciptakan Desa Wisata Fatukoto menjadi salah satu destinasi pariwisata yang favorit bagi wisatawan. 


\section{Ucapan Terima Kasih}

Ucapan terimakasih yang sebesar-besarnya diberikan untuk pemerintah desa Fatukoto melalui Kepala Desa Bapak Yosafat M. Baun, yang telah memberikan kesempatan pada Jurusan Pariwisata Politeknik Negeri Kupang untuk melakukan kegiatan pengabdian masyarakat di Desa Fatukoto, Kabupaten TTS, NTT.

\section{Referensi}

Hamzah, F., \& Utomo, E. T. (2016). Implementasi sapta pesona pada Museum Mandala Wangsit Siliwangi Kota Bandung. Jurnal Pariwisata, 3(2), 118-128. Tersedia https://ejournal.bsi.ac.id/ejurnal/index.php/jp/article/view/1467

Hudayana, B. et al. (2019). Participatory Rural Appraisal (PRA) untuk Pengembangan Desa Wisata di Pedukuhan Pucung, Desa Wukirsari, Bantul. Bakti Budaya, 2(2). Tersedia https://journal.ugm.ac.id/bakti/article/view/50890

Pariwisata, K., \& Kreatif, E. (2012). Pedoman kelompok sadar wisata. Jakarta: Kemenpar \&Ekraf.

Purwanto, M., Sari, I. M., \& Husna, H. N. (2012). Implementasi Permainan Monopoli Fisika Sebagai Media Pembelajaran Dalam Pembelajaran Kooperatif Tipe TGT Untuk Meningkatkan Prestasi Belajar dan Mengetahui Profil Kemampuan Berpikir Kritis Siswa SMP. Jurnal Pengajaran MIPA, 17(1), 69-76. Tersedia https://pdfs.semanticscholar.org/abb2/dfe4b8dc803962ed3fdb4643318c40ae40ee.pdf

Sugiyono. (2016). Metode Penelitian Kuantitatif, Kualitatif, dan R\&D. Bandung: Alfabeta

Widowati, Hari. (2019). 5 Tahun Terakhir, Rerata Pertumbuhan Kunjungan Wisatawan Mancanegara 14\%. Tersedia https://databoks.katadata.co.id/datapublish/2019/07/17/5-tahun-terakhir-reratapertumbuhan-kunjungan-wisawatan-mancanegara-14

Yoeti, O. A. (2013). Komersialisasi seni budaya dalam pariwisata. 
